\title{
SYMBOLIC BURIALS AND GRIEF \\ Coping with Trauma in the Carpathian Basin's Neolithic and Copper Age
}

ZSUZSA Hegedús ${ }^{1}$

Hungarian Archaeology Vol. 10 (2021), Issue 3, pp. 12-21. https://doi.org/10.36338/ha.2021.3.2

In the Late Neolithic and Copper Age of the Carpathian Basin, we can find several examples of burials without bodies - symbolic burials. One of the main goals of their creation may have been to give a focal point to funerary rites in cases when a member of the community could not have been laid to rest properly. Thus, we can assume they played a key role in coping with bereavement and trauma. In some cases, the analysis of the finds of symbolic burials provides an opportunity to reconstruct the identities associated with them to a certain degree.

Keywords: symbolic burials; bereavement; Neolithic; Copper Age; Carpathian Basin

Symbolic burials have been present in various cultures for thousands of years, and they are still around us today, for example in the form of war memorials. Their earliest examples in the Carpathian Basin appeared in the Late Neolithic (5000-4500/4450 BC) and the subsequent Copper Age (4500/4450-2800 BC). Their great variety in this period supports the need of summarizing our knowledge about them, paired with the exploration of their underlying meanings (HEGEDÜs in press). In this article, I mainly focus on the role that symbolic burials played in processing grief and trauma.

\section{BEREAVEMENT AS TRAUMA}

In prehistoric Europe, the Neanderthal communities were the first to bury their dead, during the Middle Palaeolithic period (about 250-50 thousand years ago) (Hovers \& BELFER-CoHen 2013, 633). Over the centuries, customs changed many times, so we might not be able to fully comprehend what kind of emotions and thoughts were behind them. Still, the bereavement linked to the death of a community member, a truly natural reaction to the loss, is a universal human phenomenon. The death of a person ruptures the social fabric, causing a loss of stability, and thus a state of shock in the survivors who are emotionally attached to the deceased (NilsSEN STUtZ \& TARLOw 2013, 7). However, the form and intensity of grief is highly variable (ARCHER 1999, 1-8), just like the processes through which it resolves. Some models in psychology break down the course of healing into steps (RANDo 1984; KÜBLER-Ross \& KeSSLER 2005; Worden 2009), while other describe it as a dynamic, ever-changing process (Stroebe \& Schut 1999). Similarly to the course of mourning, the treatment of the dead was extremely varied (Reimers 1999, 148; Fahlander \& Oestigaard 2008, 1; Nilssen Stutz \& TARLOW 2013, 6). In addition to the practicality of the burials, namely that they were ways for disposing of the corpse, the rites played a prominent role in restoring the order of everyday life. They also created a connection between the community members, both in space and time, thus reducing the threat posed by death (Assmann 2005, 28; Pérez \& Weiss-Krejci 2011, 108; Bailey \& Walter 2016, 151). Through the rites and the manipulation of the corpse, the mourners shaped the experience of death into a form that could be interpreted and processed with their own cultural tools (NiLSSEN STUtz \& TARLOw 2013, 6).

An important step, in both the processing of grief and in the rites, is that the community interacts with the corpse, which is in the focus of the funerary rites and the emotions. The corpse is not a biological phenomenon in the eyes of the mourners, but rather a person (NiLsSEn Stutz \& TARLOW 2013, 7; Kus 2013, 60).

Eötvös Loránd University, Faculty of Humanities, Doctoral School of Humanities, Archaeology Speciality, PhD Student. Email: zshegedus@s,student.elte.hu 
Not being able to get in contact with the body makes the comprehension of the experience of death much more harder (FARO 2014, 17). The absence of the corpse can also impede the course of the burial and the mourning (WeISS-KREJCI 2011, 76). If the necessary processes - both the physical and psychological ones do not take place, the members of the community may find themselves in the cripplingly traumatic state of unresolved grief (Boss 1999, 2-6). For example, if someone disappears and there is no information about their fate, the community can hold on to the irrational hope of their return (ZUR 1998, 206). The uncertainty makes the 'routine' flow of the events resulting in the resolution of grief impossible. People can get stuck in the traumatic experience, and if this cannot be resolved, they are constantly exposed to negative emotions. This might result in conflicts within the community, as the usual dynamics are disrupted, and without the necessary rites, the mutual support systems do not appear (Boss 1999, 8-24).

Because of the reasons described above, it may have been necessary for the communities to develop different, 'alternative' solutions to cope with bereavement. These provided an opportunity to commemorate the deceased, bringing the necessary emotions to the surface (WEISS-KREJCI 2013, 283-289), and through the performance of community rites, bonding and healing people (ZUR 1998, 209). Creating symbolic burials could have been such a solution. Relying on archaeological data, the reconstruction of the thoughts and goals is possible to a certain degree (COOLIDGE \& WYNN 2016, 386), thus we can get a more nuanced picture of the symbolic burials.

\section{THE ROLE OF SYMBOLIC BURIALS}

Symbolic burials can be defined as features that fit well into the burial customs of a community and use their toolkit, but have a greater potential for carrying information than 'normal' burials. Although their appearance highly resembles that of the 'average' burials, they had a wider range of functions (HEGEDÜs in press). ${ }^{2}$

One function of the symbolic burials, connected to communal mourning and coping with trauma, may have been to commemorate people whose body could not have been buried (Fig. 1). There could have been several reason why someone's body was not present at the funeral - for example, they might have disappeared, fell victim to an accident or to a violent conflict (BOGNÁR-KuTZIÁn 1963, 368-369). Nevertheless, we should not assume that every missing person who died far from home got a symbolic burial, as not everyone was given the same mortuary treatment. Several, selective behaviours were present in the postmortem treatment of the community members, including methods of body treatment that did not leave traces that archaeologists can grasp (Price 1997, 114; WeISS-KREJCI 2013, 285; KIRÁLY 2016, 279-299).

In addition to the symbolic burials focusing on coping with trauma, there are two other forms of these features. One can be characterized by outstandingly rich assemblages (CHAPMAN 2000, 127; RACHEV 2018, 51). Their main goal was not to represent a certain person, but rather to pay tribute to an abstract identity, entity or concept (STRATTON 2016, 201), that was in the focus of community rituals. In these cases, the valuable objects appearing in large quantities were able to communicate outstanding status and wealth, independently of the dead body (CHAPMAN 2000, 182; JONES 2007, 43). The third type of symbolic burials, which acted as memorials, had a more structured spatial arrangement. Their role was to symbolize several deceased people at the same time, and through them, to shape the communal memory (Jones 2007, 41; DANILOVA 2015, 11-14). Through being connected to a message - that could have been used to manipulate power as well - the dead themselves also became symbols (DANiLOva 2015, 1-6).

Overall, symbolic burials had several forms and functions, and were not only made to facilitate mourning. Yet, it was the role they played in coping with bereavement that most likely appeared first, and served as the base of such free manipulation of the funerary customs (HEGEDÜs in press). Thus, their examination can bring us closer to understanding the prehistoric communities' relationship with death.

\footnotetext{
2 The word cenotaph is sometimes used to label symbolic burials, however, it is mostly connected to the features of the Antiquity. Thus, I do not think it shall be applied to prehistoric symbolic burials. A detailed analysis of Roman cenotaphs in the Danube region was carried out by Ádám Novotnik (NovotNIK 2019).
} 


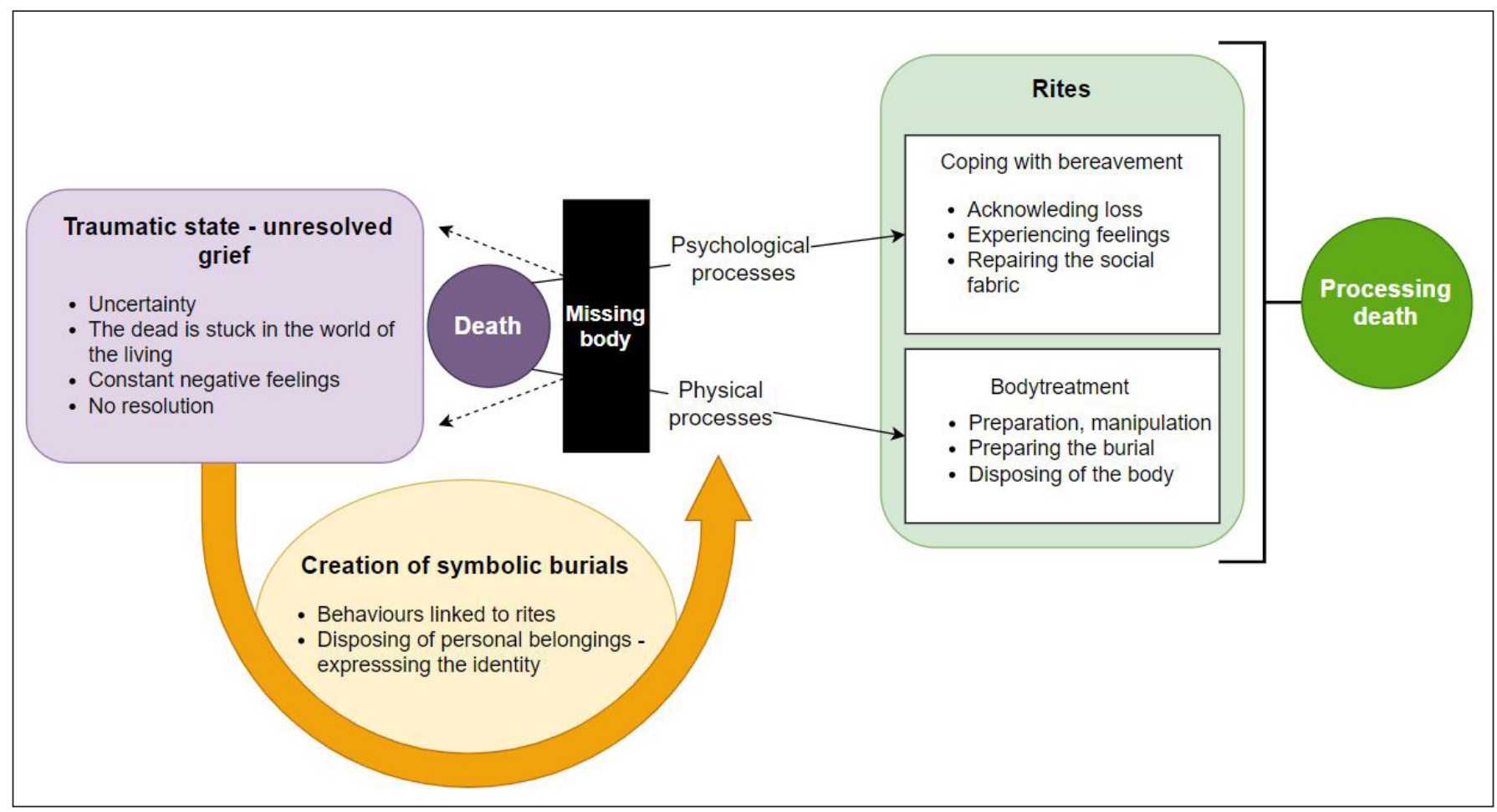

Fig. 1. In the absence of the corpse, the behaviours and rituals connected to death cannot commence properly, making it impossible to process the loss. In such cases, the creation of symbolic burials, which allows the community members to experience loss and grief, can be crucial

\section{THE EXAMINED SPACE AND TIME}

The custom of creating symbolic burials in the Carpathian Basin has its roots in the Late Neolithic (50004500/4400 BC) (BognÁR-KutZiÁn 1963, 369). This was the age of the huge tells at the Great Hungarian Plain, and of the grandiose circular ditch systems in Transdanubia. These all suggest the existence of strongly connected communities. People buried their kin in the designated areas of the settlements, sometimes with rich assemblages (RACZKY 2016; RACZKY 2019, 272-279). With the disappearance of tells, the strong social ties in the Copper Age (4500/4000-2800 BC) did not break up. This is when the first large cemeteries outside of settlements appeared. At the beginning of the Copper Age, the Late Neolithic burial customs continued, intertwined with the use of newly dominant materials used for expressing status and prestige, copper and gold (PARKINSON et al. 2010; RACZKY et al. 2014). By the Late Copper Age, the change of lifestyle and the growing mobility of communities were also reflected in the rites, for example through the emergence of cattle symbolism (RACZKY 2009; BONDÁR 2015, 281-290).

Despite all these changes, the creation of symbolic burials persisted, constantly changing and adapting to the burial customs of the given community. It should be noted that we do not encounter them in every culture of the period, only in those that put a stronger emphasis on body treatments that left archaeological evidences. For example, we do not know of symbolic burials from the Balaton-Lasinja culture, that existed in the Middle Copper Age (4000-3800 BC) in Transdanubia, but nonetheless, the number of burials we know from this culture is rather low (RegenYe 2006, 15; KöHLer 2006, 41). Communities like this might have preferred other types of funeral rites and bereavement management tools.

\section{SYMBOLIC BURIALS REPRESENTING IDENTITIES IN THE CARPATHIAN BASIN}

The past communities presumably saw certain people behind the artefacts placed into the symbolic burials representing identities (CHAPMAN 2000, 122). Thus, in their preparation the same principles might have prevailed as in the preparation of the burials where the corpse was present. During the funerary rites, there was a great emphasis on elements and artefacts that were meant to express the identity of a certain indi- 
Zsuzsa Hegedüs $\bullet$ Symbolic Burials and Grief

vidual - their characteristics that were formed by their socially important attributes and social connections (DíAZ-ANDREu \& LuCY 2005, 1-2). Although the expression of the identity may have been done in its full complexity, we must take it into account that we cannot grasp this complexity with the use of archaeological tools (Stratton \& Boric 2012, 77-78; Stratton 2016, 211; KonCz \& Szilágyi 2017). Furthermore, it must be mentioned that the data obtained from studying burials is really complex in itself (HäRKE 1997). Because of this, the interpretation of each phenomenon and assemblage is difficult, even when we work with 'complete and normal' burials. In the case of symbolic burials, the analysis is further complicated by the fact that the corpse and all the data that can be extracted from it (for example the age and the sex) is missing. These played an important role in shaping a person's identity, and thus were most likely heavily displayed in the burial.

We know of eight sites in the Carpathian Basin from which features that can be truly considered symbolic burials are known (Fig. 2). From here, I examined 32 undisturbed symbolic burials representing identities, in the context of 1180 graves in total (Hegedüs in press). ${ }^{3}$ In the case of these features, it was possible to reconstruct the person's identity to a certain degree.

The reconstruction of the identities linked to symbolic burials was based on the comparative study of the finds coming from them and the other graves of a certain site. As a given find can carry many different meanings, it is important to explore the relationship between the assemblage of the features and between the whole site's tendencies. This can be done with statistical tools that can analyse several factors simultaneously and are able to highlight hidden connections within the dataset - for example, principal component and correspondence analysis. What we can base the examination of symbolic burials on at a given site, is

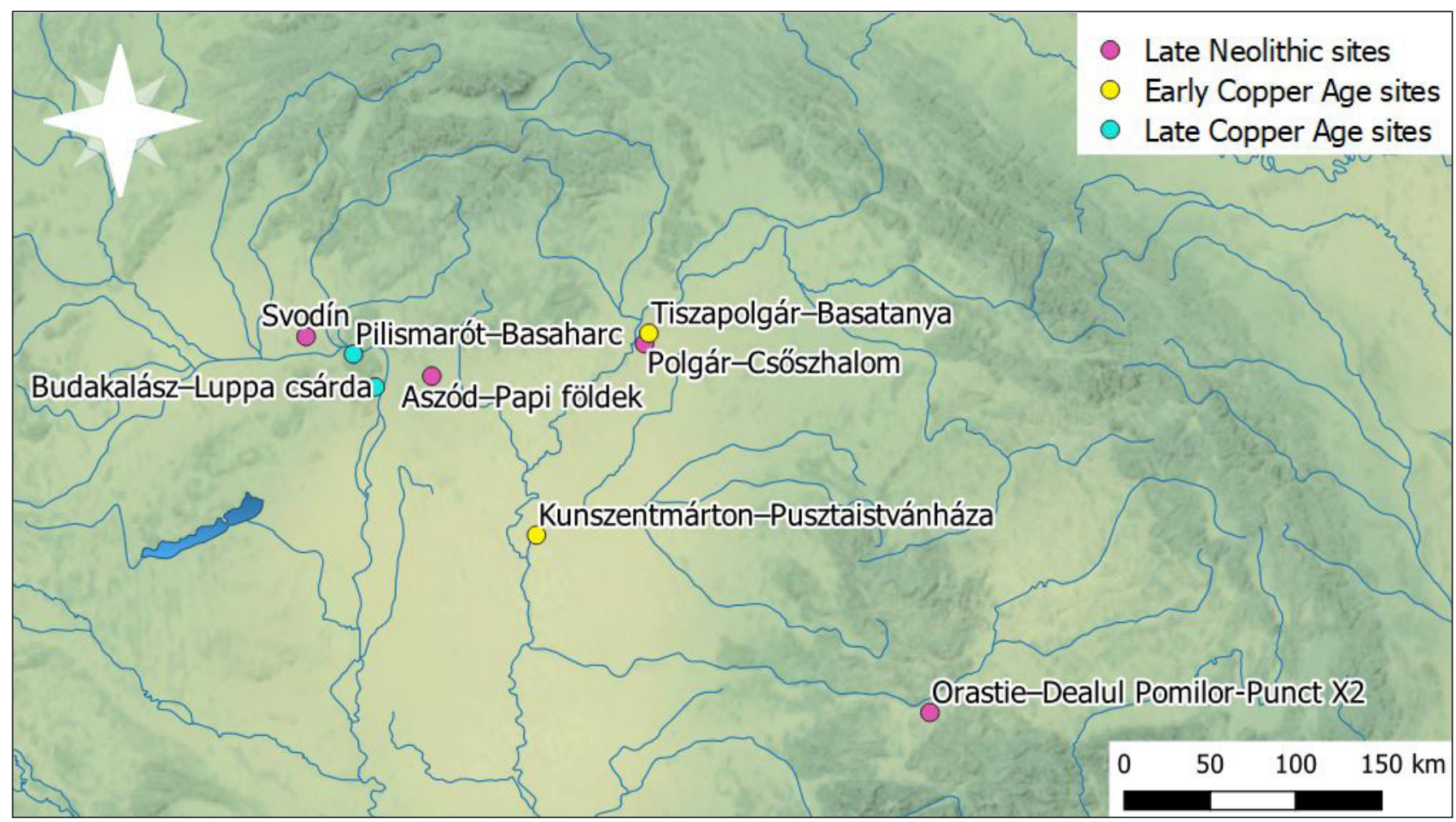

Fig. 2. Late Neolithic, Early and Late Copper Age symbolic burials of the Carpathian Basin, which represent identities

\footnotetext{
3 We know of symbolic burials from the following sites: one from Aszód-Papi földek (SikLósi 2013, 113-122) three from Budakalász-Luppa csárda (BondÁR 2009, 92-159), one from Kunszentmárton-Pusztaistvánháza (HiLleBRAND 1927, 24-28), two from Orastie-Dealul Pomilor-Punct X2/Platoul Rompos (LuCA 2006, 17-19), 21 from Pilismarót-Basaharc (BondéR 2015, 32-98), one from the horizontal settlement of Polgár-Csőszhalom (RACZKY \& ANDERS 2009, 84), two from Svodín (NemejcovÁ-Pavuková 1986, 148; Zalai-GaÁl 1988, 68), and one from Tiszapolgár-Basatanya (Bognár-KutZiÁn 1963, 77-79).
} 


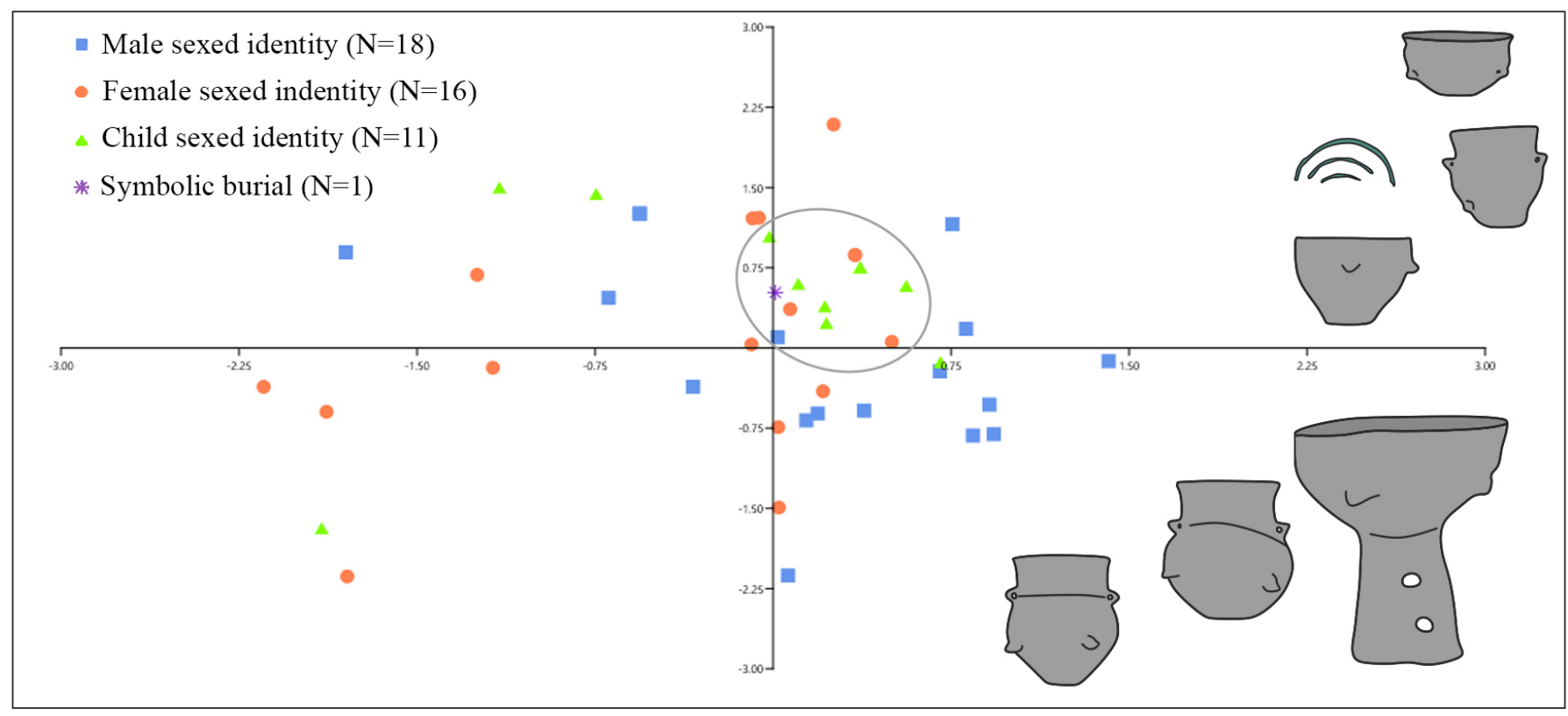

Fig. 3. Correspondence analysis of the graves furnished with Tiszapolgár-sytle ceramics from the Tiszapolgár-Basatanya site (BOGNÁR-KUTZIÁN 1963). Each grave is coloured by the sexed identity linked to the dead. Grave No. 29, the finds of which are shown on the figure, resembles child burials the most

the correlation between the biological sex of the dead and the finds they were buried with. From this, groups showing sexed identities (GOLSE 2016) can be outlined, which provides a basis of comparison for the analysis of the finds unearthed from symbolic burials. ${ }^{4}$ Thus, for example, if a wild boar mandible and a copper axe were placed in the graves of men of a certain social status, the symbolic burials containing such finds could presumably have been made for men with similar social standing.

The comparative analysis of assemblages from undisturbed burials furnished with Tiszapolgár-style ceramics of Tiszapolgár-Basatanya site (BOGNÁR-KutziÁn 1963) and the sex of the dead can outline certain groups of represented sexed identity. The greater overlap between the individual groups suggests that, although there may have been typical finds connected to each sexed identity, we cannot speak of exclusivity. The site's symbolic burial, grave No. 29 (from which vessels, fragments of copper jewellery, animal bones - including a wild boar mandible -, and limestone beads were unearthed) can be best compared to the assemblage of child burials. This is supported by the fact that the finds from graves No. 4 and 18, which were graves of children, show the most similarity to the assemblage of the symbolic burial. Also, the smaller size of the grave pit supports this idea (Fig. 3).

Using the method presented above, it was possible to reconstruct the sexed identities linked to several ones out of the 32 symbolic burials: seven can be linked to men, one to woman, and two to children. The appearance of symbolic burials of children raises an interesting question: how did the communities that created symbolic burials (and the prehistoric people in general) cope with the death of children? Despite the constant threat posed by the

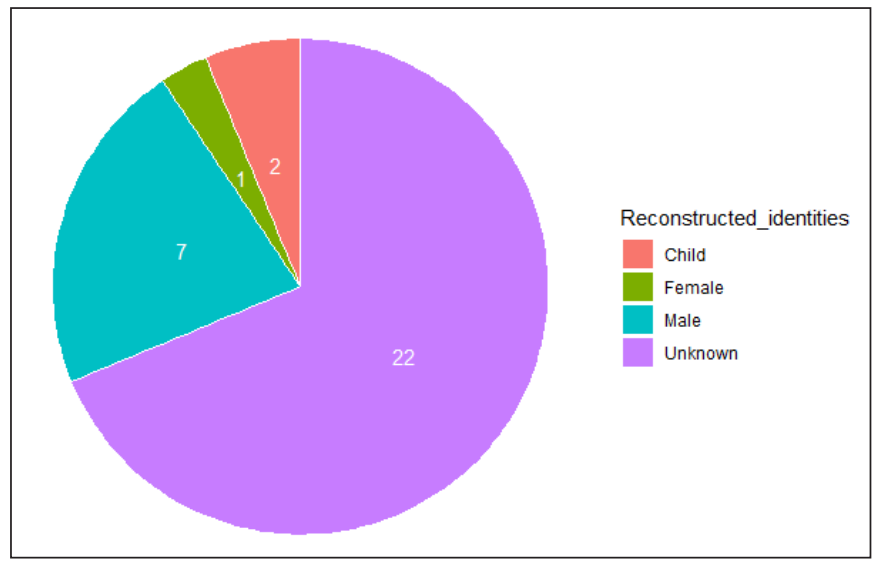

Fig. 4. Out of the symbolic burials of the Late Neolithic and Copper Age of the Carpathian Basin, a total of 32 may have been associated with individuals. The reconstruction of the sexed identity of these individuals was possible in certain cases

4 Here, besides the group of males and females, a third group appears: when the biological determination of the sex of the dead was impossible because of their young age, they were put into the child category (SOFAE DeREVENSKI 1997). 
Zsuzsa Hegedüs $\bullet$ Symbolic Burials and Grief

high child mortality rate (Goodman \& Armelagos 1989, 255), it can be assumed that communities have been shaken by the death of the youngsters, not only on an emotional and social, but also on an economic level (Thomas 2020, 4454). A type of defence mechanism might have been that the communities started considering them to be a real part of the community - and burying them accordingly - only after they reached a certain stage in life (McHugH 1999, 19-20). Based on this, the fact that children also received symbolic burials raised them to the level of adults, or close to it.

In 22 cases, no identities could be connected to symbolic burials. This is largely due to the fact that at Pilismarót-Basaharc site (BONDÁR 2015), the community cremated their dead, which in most cases made it impossible to determine the sex of the deceased (KöHLER 2015, 322). This made the reconstruction of sexed identity impossible in 21 cases (Fig. 4).

\section{CONCLUSION}

Symbolic burials were diverse features with many roles in the Late Neolithic and Copper Age of the Carpathian Basin. We find them mainly in the customs of the cultures that placed emphasis on the funerary rites that left archaeologically detectable traces. The type of symbolic burials that commemorate a certain individual played a huge role in the bereavement process and trauma treatment of the communities. Their creation can be regarded as a strategy that, in accordance to the funerary customs of each group, was suitable to treat severe emotional trauma, and potentially to resolve social tension. It is possible to reconstruct the identities symbolic burials were linked to, to a certain degree, at least. This was done in the case of each site, based on the comparative analysis of the assemblages of the graves and the sex of the dead. The analysis shows that most of the people given a symbolic burial could have been male, but features made for females and children also appear, hinting to the democratic nature of the custom. Overall, we can state that the study of empty graves - which at first glance seem to carry very little information -, is rather fruitful. It can provide important additions to the interpretation of the funerary customs and the human characteristics behind them.

\section{RECOMMENDED LITERATURE}

Boss, P. (1999). Amiguous Loss. Learning to Live with Unresolved Grief. Cambridge, London: Harvard University Press. https://doi.org/10.2307/j.ctvjhzrh4

Fahlander, F. \& Oestigaard, T. (2008). The materiality of death: bodies, burials, beliefs. In Fahlander, F. \& T. Oestigaard (eds), The Materiality of Death: Bodies, Burials, Beliefs (pp. 1-16). Oxford: Archaeopress. https://doi.org/10.30861/9781407302577

Rebay-Salisbury, K., Stig Sørensen, M.L. \& Hughes, J. (eds) (2010). Body Parts and Bodies Whole: Changing Relations and Meanings. Oxford, Oakville: Oxbow Books.

Weiss-Krejci, E. (2013). The unburied dead. In Tarlow, S. \& Nilsson Stutz, L. (eds), The Oxford Handbook of the Archaeology of Death and Burial (pp. 281-302). Oxford: Oxford University Press. https://doi. org/10.1093/oxfordhb/9780199569069.013.0016

BiBLIOGRAPHY

Archer, J. (1999). The Nature of Grief. The Evolution and Psychology of Reactions to Loss. London: Brunner-Routledge. https://doi.org/10.4324/9780203360651 
Zsuzsa Hegedüs $\bullet$ Symbolic Burials and Grief

Assmann, J. (2005). Die Lebenden und die Toten. In Assmann, J., Maciejewski, F. \& Michaels, A. (eds.), Der Abschied von Den Toten: Trauerrituale Im Kulturvergleich. (pp. 16-36) Göttingen: Wallstein Verlag. https://doi.org/10.5771/9783835320819-16

Bailey, T. \& Walter, T. (2016). Funerals against death, Mortality 21 (2), 149-166. https://doi.org/10.1080/ 13576275.2015 .1071344

Bognár-Kutzián, I. (1963). The Copper Age Cemetery of Tiszapolgár-Basatanya. Budapest: Akadémiai Kiadó.

Bondár, M., 2009, The cemetery. In Bondár, M. \& Raczky, P. (eds.), The Copper Age Cemetery of Budakalász (pp. 11-302). Budapest: Pytheas Printing House.

Bondár, M. (2015). The archaeological assessment of the Pilismarót-Basaharc cemetery. In Bondár, M., T. Bíró, K., Gál, E., Hamilton, D., Köhler, K. \& Torma, I., The Late Copper Age Cemetery at PilismarótBasaharc. István Torma's Excavations (1967, 1969-1972) (pp. 9-318). Budapest: Institute of Archaeology, Research Centre for the Humanities, Hungarian Academy of Sciences.

Boss, P. (1999). Amiguous Loss. Learning to Live with Unresolved Grief. Cambridge, London: Harvard University Press. https://doi.org/10.2307/j.ctvjhzrh4

Chapman, J. (2000). Fragmentation in Archaeology: People, Places, and Broken Objects in the Prehistory of South-Eastern Europe. London, New York: Routledge. https://doi.org/10.4324/9780203759431

Coolidge, F.L. \& Wynn, T. (2016). An introduction to cognitive archaeology. Current Directions in Psychological Science 25(6), 386-392. https://doi.org/10.1177/0963721416657085

Danilova, N. (2015). The Politics of War Commemoration in the UK and Russia. London: Palgrave Macmillan.

Díaz-Andreu, M. \& Lucy, S. (2005). Introduction. In Díaz-Andreu, M., Lucy, S., Babić, S. \& Edwards, D.N. (eds), Archaeology of Identity: Approaches to Gender, Age, Status, Ethnicity and Religion (pp. 1-12). London, New York: Routledge.

Fahlander, F. \& Oestigaard, T. (2008). The materiality of death: bodies, burials, beliefs. In Fahlander, F. \& T. Oestigaard (eds), The Materiality of Death: Bodies, Burials, Beliefs (pp. 1-16). Oxford: Archaeopress. https://doi.org/10.30861/9781407302577

Faro, L.M.C. (2014). Monuments for stillborn children: Coming to terms with the sorrow, regrets and anger. Thanatos 3 (2), 13-30.

Golse, B. (2016). Identité sexuée ou identité sexuelle? D’un genre à l'autre. Le Carnet PSY 2 (196), 1. https://doi.org/10.3917/lcp.196.0001

Goodman, A. H. \& Armelagos, G. J. (1989). Infant and childhood morbidity and mortality risks in archaeological populations. World Archaeology, 21 (2), 225-243.

Härke, H. (1997). The nature of burial data. In Jensen, C.K. \& Nielsen, K.H. (eds), Burial \& Society. The Chronological and Social Analysis of Archaeological Burial Data (pp. 19-27). Arhus: Aarhus University Press. 
Zsuzsa Hegedüs $\bullet$ Symbolic Burials and Grief

Hegedüs, Zs. (in press). Burials without bodies. The symbolic burials of the Carpathian Basin and the Lower Danube region during the Late Neolithic and Copper Age. Archaeológiai Értesitö 146.

Hillebrand, J. (1927). A pusztaistvánházai rézkori temető őstörténeti jelentőségéről. Országos Magyar Régészeti Társulat Évkönyve 2, 24-40.

Hovers, E. \& Belfer-Cohen, A. (2013). Insights into early mortuary practices of Homo. In Tarlow, S. \& Nilsson Stutz, L. (eds), The Oxford Handbook of the Archaeology of Death and Burial (pp. 632-643). Oxford: Oxford University Press. https://doi.org/10.1093/oxfordhb/9780199569069.013.0035

Jones, A. (2007) Memory and Material Culture. Cambridge: Cambridge University Press. https://doi. org/10.1017/cbo9780511619229.002

Király, Á. (2016). A terminológia halálától a halál terminológiájáig. Megjegyzések a temetkezés fogalmához és a temetkezési ciklus állomásainak nevezéktanához. Tisicum. A Jász-Nagykun-Szolnok megyei Múzeumok Évkönyve 25, 297-302.

Köhler, K. (2006) A Lengyeli és a Balaton-Lasinja kultúra embertani leletei Veszprémböl. A Veszprém Megyei Múzeumok Közleményei 24, 37-48.

Köhler, K. (2015). The human remains from the Boleráz burials uncovered at Pilismarót-Basaharc. In Bondár, M., T. Biró, K., Gál, E., Hamilton, D., Köhler, K. \& Torma, I., The Late Copper Age Cemetery at Pilismarót-Basaharc. István Torma’s Excavations (1967, 1969-1972) (pp. 319-348). Budapest: Institute of Archaeology, Research Centre for the Humanities, Hungarian Academy of Sciences.

Koncz, I. \& Szilágyi, M. (2017). Az identitás régészetének elméleti alapjai. Archaeológiai Értesítő 142, 193-215. https://doi.org/10.1556/0208.2017.142.7

Kübler-Ross, E. \& Kessler, D. (2005). On Grief \& Grieving. Finding the Meaning of Grief Through the Five Stages of Loss. New York, London, Toronto, Sydney, New Delhi: Scribner.

Kus, S. (2013). Death and the cultural entanglements of the experienced, the learned, the expressed, the contested, and the imagined. In Tarlow, S. \& Nilsson Stutz, L. (eds), The Oxford Handbook of the Archaeology of Death and Burial (pp. 60-76). Oxford: Oxford University Press. https://doi.org/10.1093/ oxfordhb/9780199569069.013.0005

Luca, S. A. (2006). La nécropole appartenant à la culture Turdas trouvée à Orăştie-Dealul Pemilor, le lieu dit X2. Acta Terra Septemcastrensis 5 (1), 13-27.

McHugh, F. (1999). Theoretical and Quantitative Approaches to the Study of Mortuary Practice. Ann Arbor: University of Michigan Press. https://doi.org/10.30861/9781841710051

Nemejcová-Pavuková, V. (1986). Vorbericht über die Ergebnisse der systematischen Grabung in Svodín in den Jahren 1971-1983. Slovenská Archeológia 24, 133-176.

Nilssen Stutz, L. \& Tarlow, S. (2013). Beautiful things and bones of desire. In Tarlow, S. \& Nilsson Stutz, L. (eds), The Oxford Handbook of the Archaeology of Death and Burial (pp. 1-15). Oxford: Oxford University Press. https://doi.org/10.1093/oxfordhb/9780199569069.013.0001 
Zsuzsa Hegedüs $\bullet$ Symbolic Burials and Grief

Novotnik, Á. (2019). Jelképes temetkezések a római császárkorban, különös tekintettel a dunai provinciákra (PhD Thesis). Pázmány Péter Katolikus Egyetem, Bölcsészettudományi Kar, Történelemtudományi Doktori Iskola, Budapest.

Parkinson, W. A., Yerkes, R. W., Gyucha, A., Sarris, A., Morris, M., \& Salisbury, R. B. (2010). Early copper age settlements in the Körös region of the Great Hungarian Plain. Journal of Field Archaeology 35 (2), 164-183. https://doi.org/10.1179/009346910x12707321520675

Pérez, V.R. \& Weiss-Krejci, E. (2011). Bridging bodies. In Lillios, K.T. (ed.), Comparative Archaeologies: Prehistoric Iberia (3000-1500 BC) and the American Southwest (A.D. 900-1600) (pp. 103-120). Oxford: Oxbow Books.

Price, R. (1997). Burial Practice and Aspects of Social Structure in the Late Chalcolithic of North-East Bulgaria (PhD Thesis). Cambridge, St. John's College, Faculty of Anthropology \& Geography, Trinity.

Rachev, R. [Рачев, Р.] (2018). Simvolichnite grobove ot k'snija eneolit (po danni ot nekropolite ot teritorijatana B'lgarija) [Символичните гробове от късния енеолит (по данни от некрополите от територията на България)] (Symbolic graves from the late Neolithic (based on necropolises in Bulgaria)). B'lgarsko e-Spisanie za Arheologija 6, 47-57.

Raczky, P. (2009). Historical context of the Late Copper Age cemetery at Budakalász. In Bondár, M. \& Raczky, P. (eds), The Copper Age Cemetery of Budakalász (pp. 475-484). Budapest: Pytheas Printing House.

Raczky, P. (2016). A Kárpát-medence népeinek anyagi kultúrája az újkőkor és a rézkor időszakában. In Vágó, Á. (ed.), A Kárpát-Medence ösi kincsei. A kökortól a honfoglalásig (pp. 21-103). Budapest: Magyar Nemzeti Múzeum Kossuth Kiadó.

Raczky, P. (2019). Cross-scale settlement morphologies and social formations in the Neolithic of the Great Hungarian Plain. In Gyucha, A. (ed.), Coming Together. Comparative Approaches to Population Aggregation and Early Urbanization (pp. 259-294). New York: State University of New York Press.

Raczky, P. \& Anders, A. (2009). Tér- és időszemlélet az újkőkorban. Polgár-Csőszhalom ásatási megfigyelései. In Anders A., Szabó M. \& Raczky, P. (eds), Régészeti dimenziók. Tanulmányok az ELTE BTK Régészettudományi Intézetének tudományos mühelyéből. A 2008. évi Magyar Tudomány Ünnepe keretében elhangzott elöadások (pp. 75-92). Budapest: Bibliotheca Archaeologica.

Raczky, P., Anders, A. \& Siklósi, Zs. (2014). Trajectories of continuity and change between the Late Neolithic and the Copper Age in Eastern Hungary. In Schier, W. \& Draşovean, F. (eds), The Neolithic and Eneolithic in Southeast Europe. New Approaches to Dating and Cultural Dynamics in the 6th to 4th Millennium BC (pp. 319-346). Rahden: Verlag Marie Leidorf GmbH.

Rando, T. A. (1984). Grief, Dying, and Death: Clinical Interventions for Caregivers. Champaign: Research Press.

Regenye, J. (2006). Temetkezések Veszprém, Jutasi út lelöhelyen. A Veszprém Megyei Múzeumok Közleményei 24, 7-36.

Reimers, E. (1999). Death and identity: Graves and funerals as cultural communication. Mortality 4 (2), 147-166. https://doi.org/10.1080/713685976 
Zsuzsa Hegedüs $\bullet$ Symbolic Burials and Grief

Siklósi, Zs. (2013). Traces of Social Inequality during the Late Neolithic in the Eastern Carpathian Basin. Budapest: Eötvös Loránd University, Institute of Archaeological Sciences.

Sofae Derevenski, J. (1997). Engendering children, engendering archaeology. In Moore, J. \& Scott, E. (eds.), Invisible People and Processes: Writing Gender and Childhood into European Archaeology (pp. 192-202). London: Leicester University Press.

Stratton, S. (2016). Burial and Identity in the Late Neolithic and Copper Age of South-East Europe (PhD Thesis). Cardiff University, School of History, Archaeology and Religion, Cardiff.

Stratton, S. \& Borič, D. (2012). Gendered bodies and objects in a mortuary domain: Comparative analysis of Durankulak cemetery. In Kogălniceanu, R., Curcă, R-G., Gligor, M. \& Stratton, S. (eds), Homines, Funera, Astra. Proceedings of the International Symposium on Funerary Anthropology. 5-8 June 2011 ' 1 Decembrie 1918'University (Alba Iulia, Romania) (pp. 71-79). Oxford: Archaeopress.

Stroebe, M. \& Schut, M. (1999). The dual process model of coping with bereavement: Rationale and description. Death Studies 23, 197-224. https://doi.org/10.1080/074811899201046

Thomas, K. J. A. (2020). Child deaths in the past, their consequences in the present, and mortality conditions in sub-Saharan Africa. Proceedings of the National Academy of Sciences of the United States of America 117 (9), 4453-4455. https://doi.org/10.1073/pnas.2000435117

Weiss-Krejci, E. (2011). The formation of mortuary deposits: Implications for understanding mortuary behavior of past populations. In Agarwal, S.C. \& Glencross, B.A. (eds), Social Bioarchaeology (pp. 68106). Chichester: Wiley-Blackwell. https://doi.org/10.1002/9781444390537.ch4

Weiss-Krejci, E. (2013). The unburied dead. In Tarlow, S. \& Nilsson Stutz, L. (eds), The Oxford Handbook of the Archaeology of Death and Burial (pp. 281-302). Oxford: Oxford University Press. https://doi. org/10.1093/oxfordhb/9780199569069.013.0016

Worden, J.W. (2009). Grief Counselling and Grief Therapy. A Handbook for the Mental Health Practitioner. New York: Springer Publishing Company. https://doi.org/10.1891/9780826101211

Zalai-Gaál, I. (1988). Közép-európai neolitikus temetök szociálarchaeológiai elemzése. A Szekszárdi Béri Balogh Ádám Múzeum Évkönyve 14, 3-178.

Zur, J. N. (1998). Violent Memories. Mayan War Widows in Guatemala. Boulder: Westview Press. https:// doi.org/10.4324/9780429503245 